\title{
The role of MMP-14 in ovarian cancer: a systematic review
}

\author{
M. Caroline $\operatorname{Vos}^{1 *} \mathbb{D}$, Anneke A. M. van der Wurff, Toin H. van Kuppevelt ${ }^{3}$ and Leon F. A. G. Massuger ${ }^{4}$
}

\begin{abstract}
Aim: In order to evaluate the role of MMP-14 in ovarian cancer, a systematic review was conducted.

Methods: In March 2020, a search in Pubmed was performed with MMP-14 and ovarian cancer as search terms. After exclusion of the references not on MMP-14 or ovarian cancer or not in English, the studies found were classified into two categories: basic research and clinicopathological research.

Results: In total, 94 references were found of which 33 were excluded. Two additional articles were found in the reference lists of the included studies. Based on the full texts, another 4 were excluded. Eventually, 59 studies were included in the review, 32 on basic research and 19 on clinicopathological research. 8 studies fell in both categories. The basic research studies show that MMP-14 plays an important role in ovarian cancer in the processes of proliferation, invasion, angiogenesis and metastasis. In clinocopathological research, MMP-14 expression is found in most tumours with characteristics of poor prognosis but this immunohistochemical MMP-14 determination does not seem to be an independent predictor of prognosis.

Conclusions: From this systematic review of the literature concerning MMP-14 in ovarian cancer it becomes clear that MMP-14 plays various important roles in the pathophysiology of ovarian cancer. The exact translation of these roles in the pathophysiology to the importance of MMP-14 in clinicopathological research in ovarian cancer and possible therapeutic role of anti-MMP-14 agents needs further elucidation.
\end{abstract}

Keywords: MMP-14, Ovarian cancer, Review, Cancer pathophysiology, Immunohistochemistry

\section{Introduction}

Ovarian cancer is known for its poor prognosis, due to the lack of effective screening methods and, therefore, its detection is usually in an advanced stage. Despite intensive treatment with surgery and chemotherapy and emerging options using targeted agents, ovarian cancer is still the leading cause of gynaecological cancer-related death in Europe and the United States. (http://gco.iarc.fr/ today/home) [1]

In search for new targets for treatment, matrixmetalloproteinases (MMPs) seem an attractive option. Members

\footnotetext{
*Correspondence: c.vos@etz.nl

${ }^{1}$ Department of Obstetrics and Gynaecology, Elisabeth-Tweesteden Hospital, PO Box 90151, 5000 LC Tilburg, the Netherlands

Full list of author information is available at the end of the article
}

of the matrix metalloproteinase (MMP) family, also known as matrixins, belong to the metzincin superfamily. They are involved in the breakdown of extracellular matrix, not only in normal physiological processes, but also in pathological processes such as inflammation and cancer. MMPs are characterized by their zinc-binding site and the necessity of the containment of zinc for their enzymatic action [2].

Apart from their action as collagenases, gelatinases and stromelysins, various other roles for MMPs in cancer have been discerned. They have an effect at the tumourcell level, intracellular actions in the nucleus [3] and in epithelial-to-mesenchymal transition and proliferation [4] and at the tumour micro-environment level, involvement in invasion, angiogenesis and metastasis [5]. In the context of inflammation, they influence T-cell inhibition original author(s) and the source, provide a link to the Creative Commons licence, and indicate if changes were made. The images or other third party material in this article are included in the article's Creative Commons licence, unless indicated otherwise in a credit line to the material. If material is not included in the article's Creative Commons licence and your intended use is not permitted by statutory regulation or exceeds the permitted use, you will need to obtain permission directly from the copyright holder. To view a copy of this licence, visit http://creativecommons.org/licenses/by/4.0/. The Creative Commons Public Domain Dedication waiver (http://creativeco mmons.org/publicdomain/zero/1.0/) applies to the data made available in this article, unless otherwise stated in a credit line to the data. 
and adhesion and macrophage inhibition [6]. Known and registered inhibitors of MMPs include the tetracyclines, of which doxycycline has been well studied [7]. Based on these results, the role of MMPs in ovarian cancer should be investigated further $[8,9]$. So far however, no therapeutic effect has been demonstrated for MMP inhibition in ovarian cancer $[10,11]$. Since then, several new targeted agents against MMPs have been developed including antibodies and one of these new agents is a MMP-14 specific nanoprobe that facilitates in vivo detection of MMP-14 tumour cells. After administration of the nanoprobe, the tumour cells with nodules as small as $125 \mu \mathrm{m}$ can be made visible with fluorescence [66].

In this review, we focus on MMP-14 (formerly identified as MT1-MMP) [12]. Most MMPs are secreted as inactive proproteins, which are activated when cleaved by extracellular proteinases [2]. However, MMP-14 is a member of the membrane-type MMP (MT-MMP) subfamily, which is characterised by a transmembrane domain, so that the MMPs are expressed at the cell surface rather than secreted [2]. In 1994, MMP-14 was the first membrane-bound MMP to be described [12] and its role on invasion and metastasis has been demonstrated in animal models [13, 14] Also, MMP-14 predicts prognosis in cancer in general according to a recent review [15].

MMP-14's main substrates are pro-MMP-2 and collagen I, but collagen II and III can also be cleaved be it to a lesser extent [2]. MMP-14 forms a dimer at the cell surface and a complex with MMP-2 and TIMP-2 (Tissue Inhibitor of MetalloProteinases 2) in order to activate MMP-2 [16-18]. It is also an enzyme for degradation of gelatine and cleavage of CD44 (a hyaluronan-receptor) [19].

MMP-14 expression varies depending on cancer type and is high in mesenchymal tumours, melanomas and brain tumours [4] and also found in hepatic tumours and in carcinomas including breast cancer [20,21]. Though MMP's and ovarian cancer were reviewed before, [22] no systematic review or meta-analysis on the role of MMP14 alone in ovarian cancer has yet been published.

\section{Methods}

On 23 March 2020, we conducted a search in Pubmed on 'MMP-14 AND ovarian cancer'. For details of the search strategy, see Additional file 1: Appendix 1.

The following exclusion criteria were used: the study was not MMP-14 or ovarian cancer or the study was not in English. After screening titles and abstracts for relevance and excluding studies on other topics, full texts of the remaining studies were assessed according to the same inclusion and exclusion criteria. By screening the reference lists of those full texts, additional references were detected and added to the search.

\section{Results}

By searching on 'MMP-14 AND ovarian cancer', a total of 94 references were found, of which 33 were excluded after screening of the titles and abstracts. The following exclusion criteria were determined: 18 studies were not on MMP-14, 11 studies were not on ovarian cancer and 4 studies were in Chinese.

Screening the reference lists of the remaining 61 studies yielded two additional articles on ovarian cancer and MMP-14.

After examining the full texts of the 63 articles, another four were excluded because the subject was only remotely on MMP-14. Eventually, 59 articles were included in this review on MMP-14 and ovarian cancer: 32 on basic research, 19 on clinicopathological research and 8 in both categories. For a flowchart of the results of the search strategy, see Fig. 1.

\section{MMP-14 and ovarian cancer in basic research}

The first study on the role of MMP-14 in ovarian cancer was performed in 1996 [23]. With Western blotting, immunohistochemistry (IHC) and immunoprecipitation, Fishman et al. demonstrated the presence of MMP-14 on the surface of cultured ovarian cancer cells derived from primary ovarian tumours, metastatic tissue and ascites.

\section{Development of cell lines, antibodies and MMP-inhibitors}

A number of studies primarily reported on the development of materials that were used: cell lines, antibodies and MMP-inhibitors [24-28]. These studies also reported that more MMP-14 expression in the developed cell lines results in more invasion in vitro.

\section{Proliferation}

There is scant evidence of the effect of MMP-14 expression on proliferation in ovarian cancer. In a model with human ovarian tumours in SCID mice, Drew et al. found that MMP-14 mRNA expression from both human tumour and mouse stromal cells was associated with increased tumour size, whereas only MMP-14 mRNA expression by human tumour cells was associated with tumour spread [29]. By cloning an antisense MMP14 into SW626 ovarian cancer cells, Wu et al. induced decreased proliferation of this cell line [30]. Liao et al. investigated hedgehog $(\mathrm{HH})$ pathway proteins, finding that increased Gli1 expression is correlated with increased MMP-14 expression and increased proliferation and invasiveness. By using inhibitors of $\mathrm{HH}$ pathway proteins, this effect was reversed and MMP-14 expression reduced [31]. Moss et al. demonstrated increased 


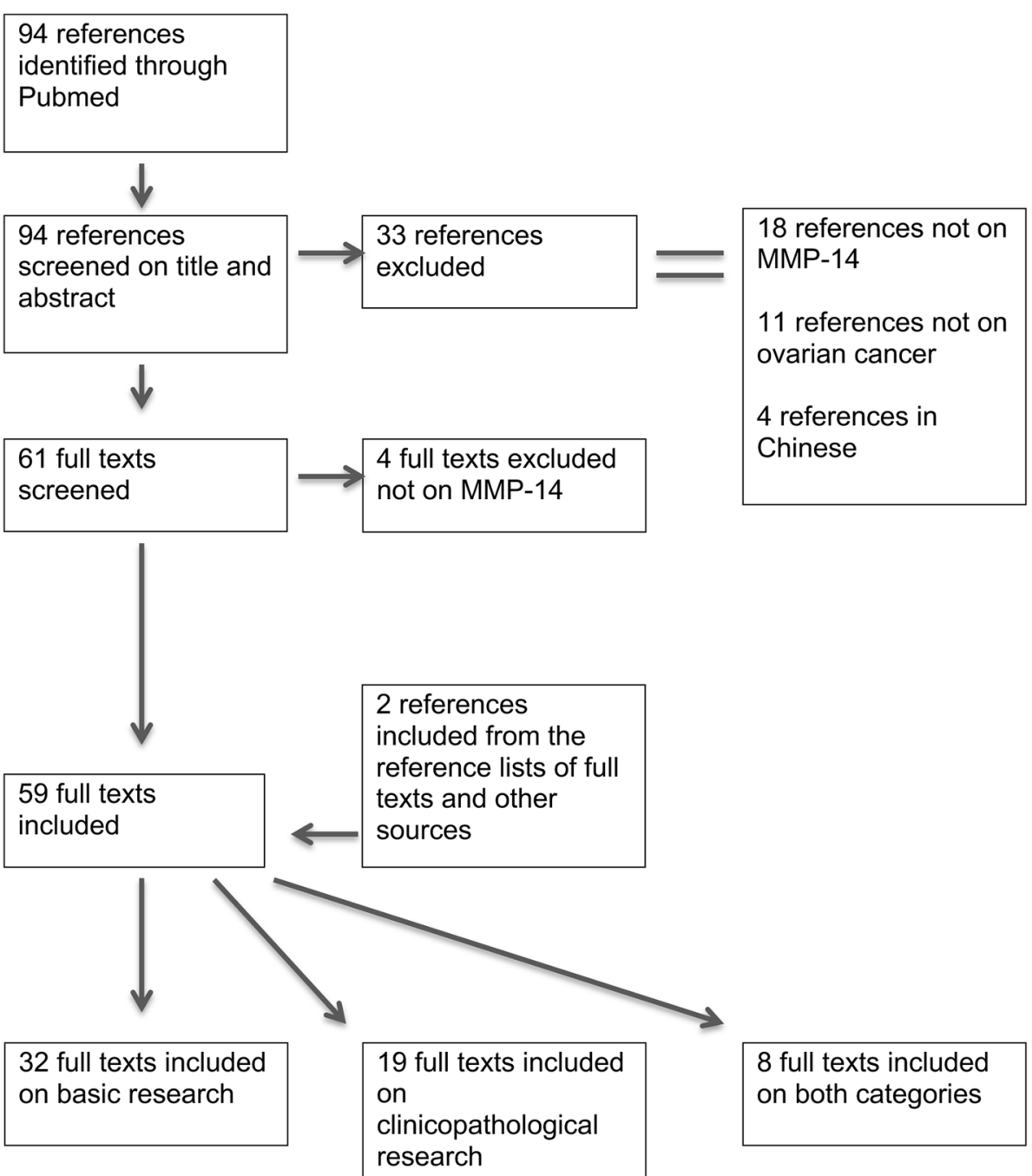

Fig. 1 Flowchart of the study

proliferation of tumour cells in three-dimensional collagens gels as a result of MMP-14 expression [32]. Koshikawa demonstrated that MMP-14 promotes heparin-binding EGF-like growth-factor-induced proliferation of ovarian cancer cells both in suspension and in collagen gel [33]. As demonstrated in a 3D collagen model, hypoxia induces MMP-14 dependent proliferation [34]. From the various models in this limited number of studies, it can be concluded that MMP-14 seems to play a role in an increase in proliferation of ovarian cancer cells.

\section{Invasion}

The first study [23] was followed by a series of studies on invasion. In the above-mentioned mouse model, Drew et al. showed that MMP-14 mRNA and protein expression by the tumour cells was associated with tumour spread intra-peritoneally [29].

MMP-14 was shown to induce activation of MMP-2 in DOV13 cells cultured on three-dimensional collagen lattice stimulated by $\beta_{1}$ integrins [35]. Further interactions between type-I collagen, $\alpha_{2} \beta_{1}$ and $\alpha_{3} \beta_{1}$ integrins, MMP-14, MMP-2 and TIMP-2 were demonstrated [36], as well as promotion by lysophosphatidic acid (LPA) [37]. Early growth response protein-1 (EGR1), but not EGR-2-4, activates MMP-14 [38]. Lee et al. demonstrated that degradation of collagen by invasive cell lines is mediated by MMP-14 through phagocytosis [39]. This mechanism is different from the mechanism described earlier $[35,36]$, though the apparent differences may be attributable to the models that were used. Agarwal et al. demonstrated that MMP-14 and MMP-9 
activate pro-MMP-1-dependent migration of OVCAR4 cells [40]. Hypoxia not only induces proliferation, but also MMP-14-dependent invasion [34]. Anti-sense MMP-14 cloned into SKOV3 cells showed a lower percentage of invasion, as well as inhibited activation of pro-MMP2 [41]. The same antisense vector was used in SW626 cells, again demonstrating the importance of MMP-14 for proliferation and invasion [30].

In contrast to these positive results on the importance of MMP-14 in invasion, Klymenko et al., in a study on cadherins, showed that mesenchymal N-cadherin-positive cells and MCAs (MultiCellular Aggregates) invade more effectively than E-cadherin-expressing cells [42]. In this study, the application of a (broad) MMP-inhibitor did not inhibit invasion fully. In a study on the application of cisplatin and a mammalian target of rapamycin (mTOR) inhibitor, invasion and migration of tumour cells was drastically impaired [43]. The expression of MMP-14 remained unchanged, but the level of activated MMP-2 was drastically reduced.

In a study on invasion and metastasis, an anti-MMP-14 antibody inhibited invasion and metastasis both in vitro and in vivo. In the in vivo mouse model intraperitoneal administration of anti-MMP-14 was combined with docetaxel, and this treatment reduced invasion of the diaphragm and development of thoracic metastases [44].

Combined, most in vitro and in vivo studies demonstrated an increase of invasion in the presence of MMP-14.

\section{Angiogenesis}

Only a limited number of studies report on the role of MMP-14 in angiogenesis in ovarian cancer. In a study on vasculogenic mimicry, Sood et al. demonstrated the formation of matrix-rich tubular networks by culturing ovarian cancer cell lines in Matrigel [45] By treating the samples with an MMP-inhibitor, the formation of the tubular networks was suppressed. Leroy-Dudal et al. demonstrated the ability of IGROV1 and SKOV3 cells to transmigrate through HUVEC (human umbilical vein endothelial cells)-derived ECM (endothelium-derived extracellular matrix) in vitro, [46] where $\alpha v$ integrins, MMP-14 and MMP-2 play an important role.

In a nude mouse model with OVCAR-4 or SKOV-3 cells, treatment with cell-penetrating pepducins targeting this cascade resulted in inhibition of PAR1-dependent angiogenesis, ascites and metastasis [40]. In another mouse model, MMP-14 was found to induce angiogenesis, and this effect was inhibited by an anti-MMP-14 antibody [44]. These few studies thus report a positive effect of MMP-14 on angiogenesis and a negative effect of MMP-14-inhibition.

\section{Metastasis}

Many of the mechanisms of invasion described above are also relevant to metastasis.

MMP-14 plays a key role in detaching cells from the primary tumour and forming multicellular aggregates (MCA) that subsequently adhere to and invade mesothelial monolayers [32]. These MCAs exhibit more aggressive behaviour than single cells. The submesothelial matrix is rich in collagen type I and III, and MMP-14 is necessary for adherence to and invasion in this matrix. The post-translational phosphorylation of the cytoplasmatic tail of MMP-14 at $\mathrm{Thr}^{567}$ influences the behaviour of individual cells and MCAs. Enhanced phosphorylation results in detachment of cell-cell adherent sheets and increased cell migration [32]. The MCAs with enhanced phosphorylation show increased adherence to peritoneum and this adherence degrades mesothelial integrity [47]. Co-expression of integrin-linked kinase (ILK) and MMP-14 results in phosphorylation of the cytoplasmatic tail of MMP-14 with increased cell-cell detachment, migration, adherence to the peritoneum and degradation of mesothelial integrity [48].

\section{Interactions of MMP-14 with other molecules}

Several studies have investigated the interactions between MMP-14 and other molecules. From the very first study onwards, the action of MMP-14 as the main activator of MMP-2 has repeatedly been demonstrated by zymography, as have the presence and inhibitory effect of TIMP-2 [23, 35].

A very interesting finding is the inverse relationship between MMP-14 and MUC16/CA-125. CA 125 is an antigen which is known for its diagnostic and prognostic value in ovarian cancer. MMP-14 overexpression causes increased ectodomain shedding of MUC16/CA 125. By the increased ectodomain shedding of MUC16/Ca 125, integrins on the cell surface may become exposed resulting in increased adhesion and invasion [49]. The interactions between MMP-14 and the integrins have been extensively studied as discussed above. The results of these studies and studies on other molecules are summarised in Table 1.

\section{Synopsis of findings on MMP-14 in ovarian cancer in basic research}

In ovarian cancer, MMP-14 seems to play an important role in invasion and metastasis as well as in proliferation and angiogenesis, though the latter two processes have been less well studied. In most studies with a controlled design, the presence or expression of MMP-14 led to more invasion and metastasis as well as proliferation and angiogenesis. The growth and spread of ovarian cancer 


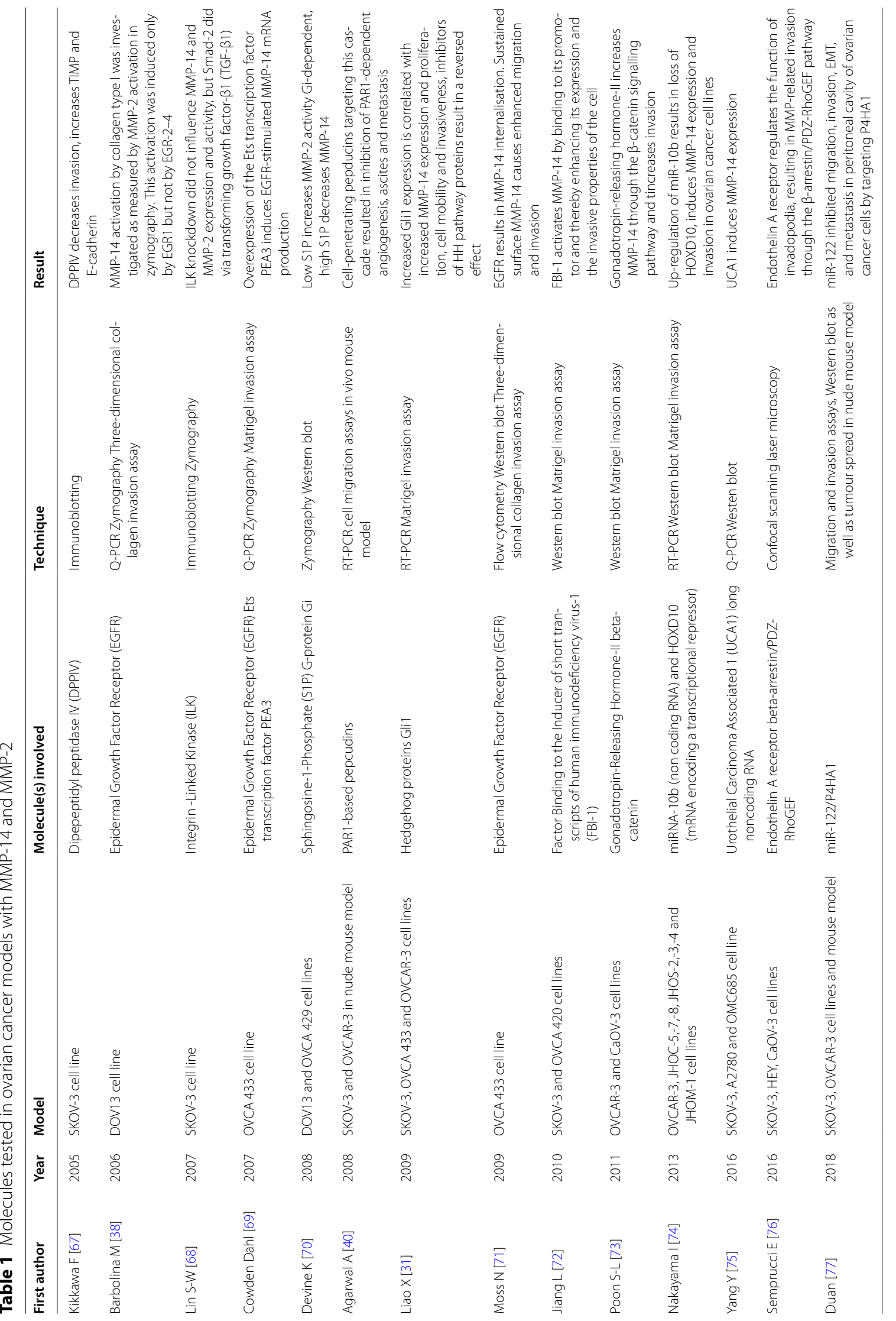


can be orchestrated by MMP-14 in conjunction with other molecules including MMP-2, TIMP-2 and the integrins. However, none of these players including MMP-14 seems to be essential as invasion can also occur without the influence of MMP-14 but is then usually less extensive [42, 44]. Differences between the studies discussed above may mostly be attributable to the models and materials used in the studies.

MMP-14 and ovarian cancer in clinicopathological research Although most basic research studies have a controlled design, translation of the findings in cell lines to patients is not straightforward. MMP-14 has been studied in patient material with various techniques. The first studies performed were with the technique of in-situ hybridization (ISH). MMP-14 has also been determined in serum. One study investigated MMP-14 polymorphisms [50]. However, most studies have been performed with IHC and compared benign tumours, borderline ovarian tumours and ovarian cancer.

\section{In-situ hybridization}

Initially, Afzal et al. investigated MMP_14 mRNA in-situ hybridization (ISH) in different type ovarian tumours [51]. Few benign tumours, but six borderline tumours showed MMP-14 mRNA expression. Of the malignant tumours, only one was negative for tumour cells and stroma, and 18/19 showed MMP-14 mRNA expression in the stroma, of which $8 / 19$ also showed expression in the epithelium.

The first study on MMP-14 mRNA expression and survival was by Davidson et al.[52] They investigated 45 patients, of which 21 were long-term survivors (mean disease-free survival of 109 months (DFS) and mean overall survival (OS) of 125 months), and 24 were shortterm survivors (mean DFS three months and mean OS of 21 months). MMP-14 mRNA expression in tumour cells of the metastasis correlated with poor survival, while expression in the stromal cells correlated with longer survival. These findings have contributed to the hypothesis that MMP-14 on the tumour cells indicates more aggressive tumour characteristics and that MMP-14 in the stroma is part of the anti-tumour response by the host. In a follow-up study also considering angiogenic factors, no correlation between MMP-14 and angiogenic factors was found [53]. Part of the cohort was also studied for correlation between the MMPs and integrins, as well as correlation between Ets transcription factors and MMP-14 [54]. This study suggested that MMP-synthesis occurs after integrin activation. However, these findings in tumour tissue are not in line with the basic research on the DOV13 cell line [35, 36].
Davidson et al. also studied a different cohort, where the results for reverse transcriptase polymerase chain reaction (RT-PCR) and ISH correlated well [55]. No differences in expression were found between peritoneal and pleural effusions suggesting that the cells in peritoneal and pleural effusions are similar.

\section{Serum MMP-14}

Serum MMP-14 was determined in a small series of fluids (cystic, ascites and pleural effusions) from 14 patients, 10 of them being malignant and demonstrating a threefold increase compared to benign fluids. In a series of 92 serum samples, 26 from patients with ovarian cancer, MMP-14 was found to be significantly increased in the ovarian cancer patients compared to those with benign masses or healthy females [44]. This is an interesting finding, given the increased ectodomain shedding by increased expression of MMP-14 of MUC16/CA 125 [49].

\section{Immunohistochemistry}

For an overview of the relevant clinicopathological studies using IHC and their main findings, see Table 2. Details about the studies can be found in this table.

In most studies, malignant and borderline tumours, showed higher MMP-14 expression than benign tumours [56]. Various studies showed a correlation with poor prognostic factors such as high stage and high grade. Strong epithelial MMP-14 expression and high stromal MMP-14 were significant factors in multivariate analysis in one study [57]. In our study on lymphogenic and hepatogenic metastasis, all tumours were MMP-14 positive [58].

Sometimes a correlation with survival is found [59]. However, in a study by Brun et al., the expression of epithelial MMP-14 appeared to predict survival but this effect disappeared after Bonferroni correction [60]. We did also not find that MMP-14 was an independent prognostic factor [58, 61, 62].

Paulsen et al. investigated 99 serous borderline ovarian tumours, of which 44 had non-invasive implants. The results were not significantly different between the noninvasive implant group and the group without implants. All samples from the seven patients who relapsed, were strongly positive for MMP-14 [63]. Moss et al. studied 17 patients in which the peritoneal metastasis showed either similar or increased MMP-14 expression compared to the primary tumour [32].

In the studies, where both MMP-14 and MMP-2 were studied, their expression mostly correlated [61, 64].

Barbolina et al. demonstrated that the highest expression of MMP-14 was in clear-cell carcinomas (94\%) [38]. Clear-cell carcinomas showed high expression with 17/18 


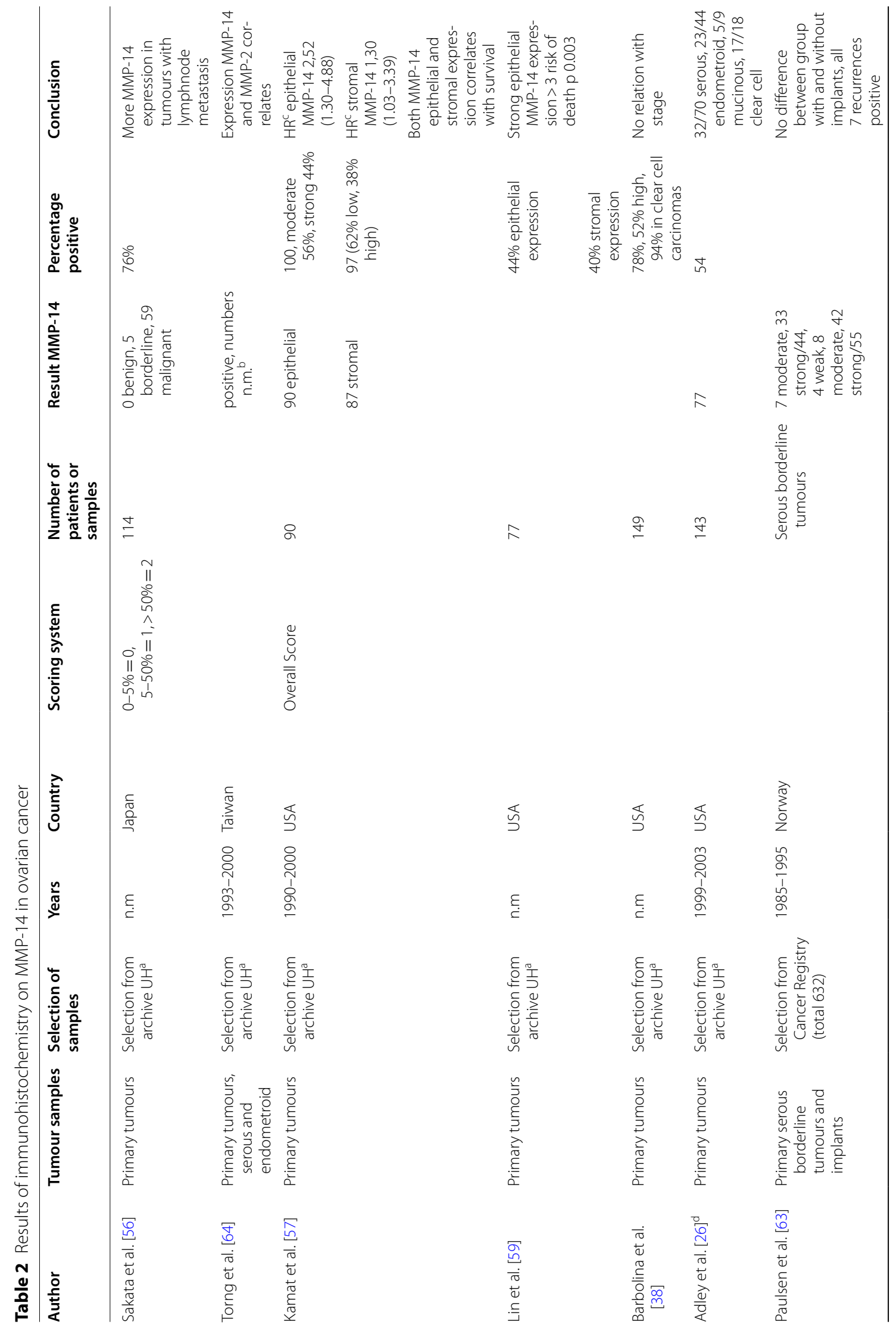




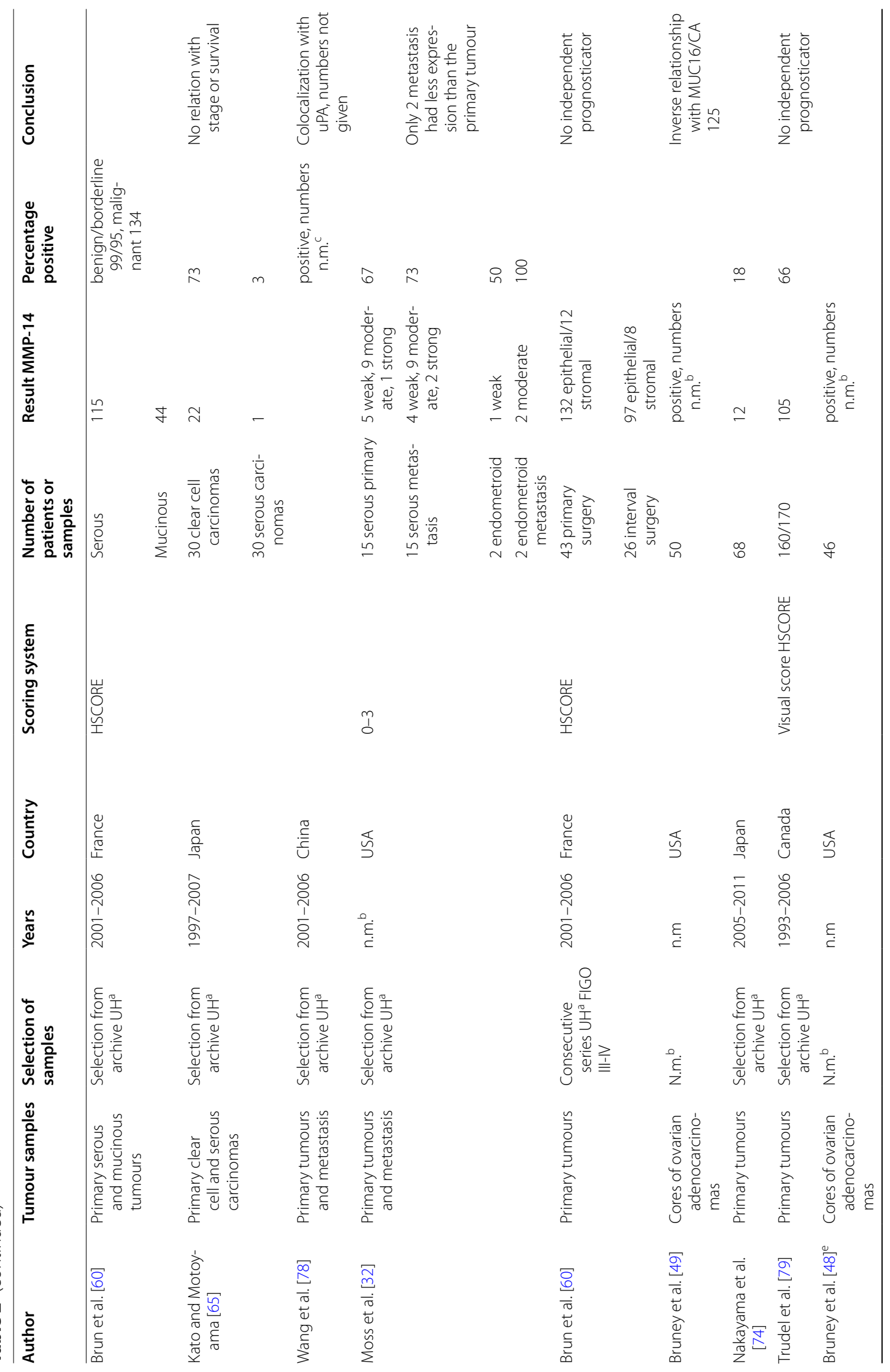




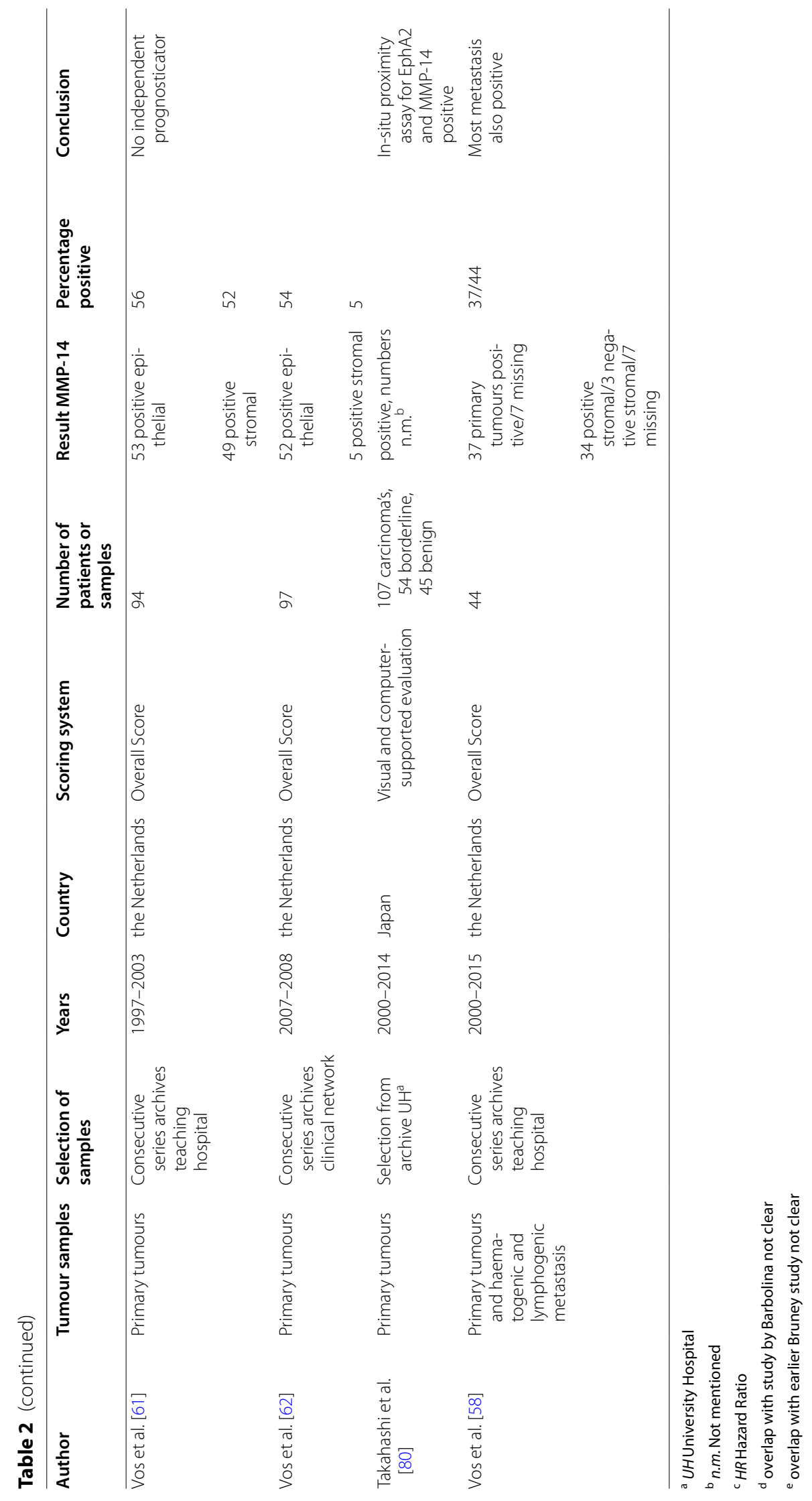


samples with positive expression compared to the other histiotypes, in which expression was $45-55 \%$ in another study by the same group [26]. However, the overlap between these studies was not clear. A study from Japan confirmed high MMP-14 expression in 22/30 clear cell carcinomas, while only $1 / 30$ serous carcinomas was positive without correlation with stage or survival [65]. In a French study, serous tumours, especially the malignant ones, showed higher MMP-14 expression than the mucinous tumours [60].

\section{Synopsis of findings on MMP-14 IHC in ovarian cancer}

The wide range of MMP-14 expression measured in these studies may be explained by several factors. One is the use of a variety of antibodies and the fact that most of them were polyclonal. The disadvantage of using polyclonal antibodies is that they bind not only to intact or active MMP-14 but also to its degraded products. Therefore, more background staining is to be expected.

A second possible explanation for the wide range of results is the use of several different scoring systems for MMP-14 expression, most of which were semi-quantitative, which may result in a low discriminative value. Unfortunately, no large validation studies on these scoring systems have yet been conducted. The use of the HSCORE seems a promising tool due to the use of an objective count and possible wider range of scores [64].

A third possible factor is non-uniformity and lack of clarity in the selection of patient cohorts. As some of the studies do not report the selection criteria used, this aspect is impossible to investigate.

Finally, limited data are available on overall and disease-free survival outcomes. In the review on MMP-14 expression on cancer in general [15], MMP-14 was an independent prognosticator. For ovarian cancer however, the data on survival are limited. In the few studies that are available on survival, MMP-14 is related to prognostic factors and (disease-free) survival, but its independent value turns out to be limited after correction for known prognostic factors or statistical correction for the number of tests.

\section{Conclusion}

From this systematic review of current knowledge regarding the role of MMP-14 in ovarian cancer, MMP14 comes to the forefront as an important molecule in the pathophysiology of ovarian cancer. Basic research shows that it plays a role in proliferation, invasion, angiogenesis and metastasis. However, MMP-14 does not seem to be an essential player because in some studies invasion is possible without MMP-14, though in the presence of MMP-14 invasion and metastasis is more extensive. Although the development of advanced tumours is mediated through several pathways, MMP14 expression occurs in most advanced-stage ovarian cancers and not in all early-stage tumours. The limited available research on survival indicates that MMP-14 is not an independent predictor for prognosis. This may be due to several limitations in the studies, but also to the fact that in ovarian cancer other prognostic factors may overrule the role of MMP-14.

Therefore, we recommend larger validation studies of the IHC scoring systems for MMP-14 in order to determine the predictive role of MMP-14 more precisely. However, the heterogeneity of expression within the tumour may still be a limiting factor.

Ideally, monoclonal antibodies are used for these IHC studies and also tested for their therapeutic effect in MMP inhibition. In the past, generalized MMP-14 inhibition has not shown to be effective. By identifying the precise mechanisms whereby MMP-14 stimulates tumour growth, anti-MMP agents that have a targeted action are developed and can be tested in a minimal residual disease setting after debulking.

Given the widespread presence of MMP-14 in advanced-stage disease, these new targeted agents may be used in spite of the limited prognostic value of MMP-14. If a given tumour is MMP-14 positive irrespective of its histological type, targeted treatment can be administered after debulking with chemotherapy and surgery if necessary and hopefully lead to prolonged responses to treatment. A promising new development is a MMP-14 specific nanoprobe that facilitates in vivo detection of MMP-14 tumour cells. This nanoprobe can be used during debulking surgery and therefore be an attractive therapeutic tool for success of debulking surgery [66].

\section{Supplementary Information}

The online version contains supplementary material available at https://doi. org/10.1186/s13048-021-00852-7.

Additional file 1: Appendix 1. Search strategy for MMP-14 and ovarian cancer.

\section{Acknowledgements}

The authors wish to thank mrs. Godelieve Engbersen, medical information specialist for help with the search strategy.

\section{Code availability}

Not applicable.

\section{Authors' contributions}

MCV designed the study, performed the literature search and drafted the manuscript. AvdW supervised the extraction of the data, TVK and LM supervised the work. All authors participated in critical discussions and manuscript editing. The authors read and approved the final manuscript.

Funding

No funding was received for conducting this study. 
Availability of data and materials

Not applicable.

\section{Declarations}

\section{Ethics approval and consent to participate}

Not applicable.

\section{Consent for publication}

Not applicable.

\section{Competing interests}

The authors declare that they have no conflict of interest.

\section{Author details}

${ }^{1}$ Department of Obstetrics and Gynaecology, Elisabeth-Tweesteden Hospital, PO Box 90151, 5000 LC Tilburg, the Netherlands. '2Department of Pathology, Elisabeth-Tweesteden Hospital, PO Box 90151, 5000 LC Tilburg, the Netherlands. ${ }^{3}$ Department of Biochemistry, Radboud Institute for Molecular Life Sciences, Radboud University Medical Centre, PO Box 9101, 6500 HB Nijmegen, the Netherlands. ${ }^{4}$ Department of Obstetrics and Gynaecology, Radboud University Nijmegen Medical Centre, PO Box 9101, 6500 HB Nijmegen, the Netherlands.

Received: 23 December 2020 Accepted: 23 July 2021

Published online: 03 August 2021

\section{References}

1. Siegel RL, Miller KD, Jemal A. Cancer statistics, 2018. CA Cancer J Clin. 2018;68(1):7-30.

2. Amar S, Smith L, Fields GB. Matrix metalloproteinase collagenolysis in health and disease. Biochim Biophys Acta Mol Cell Res. 2017:1864(11):1940-51.

3. Wali N, Hosokawa K, Malik S, Saito H, Miyaguchi K, Imajoh-Ohmi S, Miki Y, Nakanishi A. Centrosomal BRCA2 is a target protein of membrane type-1 matrix metalloproteinase (MT1-MMP). Biochem Biophys Res Commun. 2014;443(4):1148-54.

4. Turunen SP, Tatti-Bugaeva O, Lehti K. Membrane-type matrix metalloproteases as diverse effectors of cancer progression. Biochim Biophys Acta. 2017:1864(11 Pt A):1974-88.

5. Jiang WG, Davies G, Martin TA, Parr C, Watkins G, Mason MD, Mansel RE. Expression of membrane type-1 matrix metalloproteinase, MT1MMP in human breast cancer and its impact on invasiveness of breast cancer cells. Int J Mol Med. 2006:17(4):583-90.

6. Jiang WG, Sanders AJ, Katoh $M$, Ungefroren $H$, Gieseler F, Prince $M$, Thompson SK, Zollo M, Spano D, Dhawan P, Sliva D, Subbarayan PR, Sarkar M, Honoki K, Fujii H, Georgakilas AG, Amedei A, Niccolai E, Amin A, Ashraf SS, Ye L, Helferich WG, Yang X, Boosani CS, Guha G, Ciriolo MR, Aquilano K, Chen S, Azmi AS, Keith WN, Bilsland A, Bhakta D, Halicka D, Nowsheen S, Pantano F, Santini D. Tissue invasion and metastasis: Molecular, biological and clinical perspectives. Semin Cancer Biol. 2015;35(Suppl):S244-75.

7. Gialeli C, Theocharis AD, Karamanos NK. Roles of matrix metalloproteinases in cancer progression and their pharmacological targeting. FEBS J. 2011;278(1):16-27.

8. Cui N, Hu M, Khalil RA. Biochemical and Biological Attributes of Matrix Metalloproteinases. Prog Mol Biol Transl Sci. 2017;147:1-73.

9. Liu J, Khalil RA. Matrix metalloproteinase inhibitors as investigational and therapeutic tools in unrestrained tissue remodeling and pathological disorders. Prog Mol Biol Transl Sci. 2017;148:355-420.

10. Hirte H, Vergote IB, Jeffrey JR, Grimshaw RN, Coppieters S, Schwartz B, Tu $D$, Sadura A, Brundage M, Seymour L. A phase III randomized trial of BAY 12-9566 (tanomastat) as maintenance therapy in patients with advanced ovarian cancer responsive to primary surgery and paclitaxel/platinum containing chemotherapy: a National Cancer Institute of Canada Clinical Trials Group Study. Gynecol Oncol. 2006;102(2):300-8.

11. Winer A, Adams S, Mignatti P. Matrix metalloproteinase inhibitors in cancer therapy: turning past failures into future successes. Mol Cancer Ther. 2018:17(6):1147-55.
12. Sato H, Takino T, Okada Y, Cao J, Shinagawa A, Yamamoto E, Seiki M. A matrix metalloproteinase expressed on the surface of invasive tumour cells. Nature. 1994:370(6484):61-5.

13. Sabeh F, Ota I, Holmbeck K, Birkedal-Hansen H, Soloway P, Balbin M Lopez-Otin C, Shapiro S, Inada M, Krane S, Allen E, Chung D, Weiss SJ. Tumor cell traffic through the extracellular matrix is controlled by the membrane-anchored collagenase MT1-MMP. J Cell Biol. 2004;167(4):769-81.

14. Szabova L, Chrysovergis K, Yamada SS, Holmbeck K. MT1-MMP is required for efficient tumor dissemination in experimental metastatic disease. Oncogene. 2008;27(23):3274-81.

15. Zhang L FAU - Jin, Shan, Jin S FAU - Wei, Yuanfeng, Wei Y FAU - Wang, Chengyan, Wang C FAU - Zou, Hong, Zou H FAU - Hu, Jianming, Hu J FAU - Jia, Wei, Jia W FAU - Pang, Lijuan, Pang L. Prognostic Significance of Matrix Metalloproteinase 14 in Patients with Cancer: a Systematic Review and Meta-Analysis. Clin Lab. 2020;66(5).

16. Ingvarsen S, Madsen DH, Hillig T, Lund LR, Holmbeck K, Behrendt N, Engelholm LH. Dimerization of endogenous MT1-MMP is a regulatory step in the activation of the 72-kDa gelatinase MMP-2 on fibroblasts and fibrosarcoma cells. Biol Chem. 2008;389(7):943-53.

17. Itoh Y, Ito N, Nagase H, Evans RD, Bird SA, Seiki M. Cell surface collagenolysis requires homodimerization of the membrane-bound collagenase MT1-MMP. Mol Biol Cell. 2006;17(12):5390-9.

18. Itoh $Y$, Ito $N$, Nagase $H$, Seiki M. The second dimer interface of MT1-MMP, the transmembrane domain, is essential for ProMMP-2 activation on the cell surface. J Biol Chem. 2008;283(19):13053-62.

19. Yoshizaki T, Sato H, Furukawa M. Recent advances in the regulation of matrix metalloproteinase 2 activation: from basic research to clinical implication (Review). Oncol Rep. 2002;9(3; 1021-335):607-11.

20. Mylona E, Nomikos A, Magkou C, Kamberou M, Papassideri I, Keramopoulos A, Nakopoulou L. The clinicopathological and prognostic significance of membrane type 1 matrix metalloproteinase (MT1-MMP) and MMP-9 according to their localization in invasive breast carcinoma. Histopathology. 2007;50(3):338-47.

21. Shanbhogue AK, Prasad SR, Takahashi N, Vikram R, Sahani DV. Recent advances in cytogenetics and molecular biology of adult hepatocellular tumors: implications for imaging and management. Radiology. 2011;258(3):673-93.

22. Al-Alem L, Curry TE. Ovarian cancer: involvement of the matrix metalloproteinases. Reproduction. 2015;150(2):R55-64

23. Fishman DA, Bafetti LM, Stack MS. Membrane-type matrix metalloproteinase expression and matrix metalloproteinase-2 activation in primary human ovarian epithelial carcinoma cells. Invasion Metastasis. 1996;16(3):150-9.

24. Nishikawa A, Iwasaki M, Akutagawa N, Manase K, Yamashita S, Endo T, Kudo R. Expression of various matrix proteases and Ets family transcriptional factors in ovarian cancer cell lines: correlation to invasive potential. Gynecol Oncol. 2000;79(2):256-63.

25. Sodek KL, Ringuette MJ, Brown TJ. MT1-MMP is the critical determinant of matrix degradation and invasion by ovarian cancer cells. Br J Cancer. 2007:97(3):358-67.

26. Adley BP, Gleason KJ, Yang XJ, Stack MS. Expression of membrane type 1 matrix metalloproteinase (MMP-14) in epithelial ovarian cancer: high level expression in clear cell carcinoma. Gynecol Oncol. 2009;112(2):319-24.

27. Chenard MP, Lutz Y, Mechine-Neuville A, Stoll I, Bellocq JP, Rio MC, Basset P. Presence of high levels of MT1-MMP protein in fibroblastic cells of human invasive carcinomas. Int J Cancer. 1999;82(2):208-12.

28. Marques SM, Abate CC, Chaves S, Marques F, Santos I, Nuti E, Rossello A, Santos MA. New bifunctional metalloproteinase inhibitors: an integrated approach towards biological improvements and cancer therapy. J Inorg Biochem. 2013;127:188-202

29. Drew AF, Blick TJ, Lafleur MA, Tim EL, Robbie MJ, Rice GE, Quinn MA Thompson EW. Correlation of tumor- and stromal-derived MT1-MMP expression with progression of human ovarian tumors in SCID mice. Gynecol Oncol. 2004;95(3):437-48.

30. Wu M, Xu G, Xi L, Wei J, Song A, Han Z, Zhou J, Wang S, Zhu T, Zhang A, LuY, Ma D. Down-regulation of MT1-MMP expression suppresses tumor cell invasion in metastatic human SW626 ovarian cancer cells. Oncol Rep. 2006;15(2; 1021-335; 1021-335):501-5.

31. Liao X, Siu MK, Au CW, Wong ES, Chan HY, Ip PP, Ngan HY, Cheung AN. Aberrant activation of hedgehog signaling pathway in ovarian cancers: 
effect on prognosis, cell invasion and differentiation. Carcinogenesis. 2009;30(1):131-40.

32. Moss NM, Barbolina MV, Liu Y, Sun L, Munshi HG, Stack MS. Ovarian cancer cell detachment and multicellular aggregate formation are regulated by membrane type 1 matrix metalloproteinase: a potential role in I.p. metastatic dissemination. Cancer Res. 2009;69(17):7121-9.

33. Koshikawa N, Mizushima H, Minegishi T, Eguchi F, Yotsumoto F, Nabeshima K, Miyamoto S, Mekada E, Seiki M. Proteolytic activation of heparin-binding EGF-like growth factor by membrane-type matrix metalloproteinase-1 in ovarian carcinoma cells. Cancer Sci. 2011;102(1):111-6.

34. Sun L, Lin P, Qin Z, Liu Y, Deng LL, Lu C. Hypoxia promotes HO-8910PM ovarian cancer cell invasion via Snail-mediated MT1-MMP upregulation. Exp Biol Med (Maywood). 2015;240(11):1434-45.

35. Ellerbroek SM, Fishman DA, Kearns AS, Bafetti LM, Stack MS. Ovarian carcinoma regulation of matrix metalloproteinase-2 and membrane type 1 matrix metalloproteinase through beta1 integrin. Cancer Res 1999;59(7):1635-41.

36. Ellerbroek SM, Wu YI, Overall CM, Stack MS. Functional interplay between type I collagen and cell surface matrix metalloproteinase activity. J Biol Chem. 2001;276(27):24833-42.

37. Fishman DA, Liu Y, Ellerbroek SM, Stack MS. Lysophosphatidic acid promotes matrix metalloproteinase (MMP) activation and MMP-dependent invasion in ovarian cancer cells. Cancer Res. 2001;61(7):3194-9.

38. Barbolina MV, Adley BP, Ariztia EV, Liu Y, Stack MS. Microenvironmental regulation of membrane type 1 matrix metalloproteinase activity in ovarian carcinoma cells via collagen-induced EGR1 expression. J Biol Chem. 2007;282(7):4924-31.

39. Lee H, Sodek KL, Hwang Q, Brown TJ, Ringuette M, Sodek J. Phagocytosis of collagen by fibroblasts and invasive cancer cells is mediated by MT1MMP. Biochem Soc Trans. 2007;35:704-6.

40. Agarwal A, Covic L, Sevigny LM, Kaneider NC, Lazarides K, Azabdaftari G, Sharifi S, Kuliopulos A. Targeting a metalloprotease-PAR1 signaling system with cell-penetrating pepducins inhibits angiogenesis, ascites, and progression of ovarian cancer. Mol Cancer Ther. 2008;7(9):2746-57.

41. Wu M, Shi Y, Xi L, Li Q, Liao GN, Han ZQ, Lu YP, Ma D. Construction of antisense MT1-MMP vector and its inhibitory effects on invasion of human ovarian cancer cells. J Huazhong Univ Sci Technolog Med Sci. 2005:25(6):715-7.

42. Klymenko Y, Kim O, Loughran E, Yang J, Lombard R, Alber M, Stack MS. Cadherin composition and multicellular aggregate invasion in organotypic models of epithelial ovarian cancer intraperitoneal metastasis. Oncogene. 2017;36(42):5840-51.

43. Karam AK, Santiskulvong C, Fekete M, Zabih S, Eng C, Dorigo O. Cisplatin and PI3kinase inhibition decrease invasion and migration of human ovarian carcinoma cells and regulate matrix-metalloproteinase expression. Cytoskeleton (Hoboken ). 2010;67(8):535-44.

44. Kaimal R, Aljumaily R, Tressel SL, Pradhan RV, Covic L, Kuliopulos A, Zarwan C, Kim YB, Sharifi S, Agarwal A. Selective blockade of matrix metalloprotease-14 with a monoclonal antibody abrogates invasion, angiogenesis, and tumor growth in ovarian cancer. Cancer Res. 2013;73(8):2457-67.

45. Sood AK, Seftor EA, Fletcher MS, Gardner LM, Heidger PM, Buller RE, Seftor RE, Hendrix MJ. Molecular determinants of ovarian cancer plasticity. Am J Pathol. 2001;158(4):1279-88.

46. Leroy-Dudal J, Demeilliers C, Gallet O, Pauthe E, Dutoit S, Agniel R, Gauduchon P, Carreiras F. Transmigration of human ovarian adenocarcinoma cells through endothelial extracellular matrix involves alphav integrins and the participation of MMP2. Int J Cancer. 2005;1 14(4):531-43.

47. Yang J, Kasberg WC, Celo A, Liang Z, Quispe K, Stack MS. Post-translational modification of the membrane type 1 matrix metalloproteinase (MT1MMP) cytoplasmic tail impacts ovarian cancer multicellular aggregate dynamics. J Biol Chem. 2017;292(32):13111-21.

48. Bruney L, Liu Y, Grisoli A, Ravosa MJ, Stack MS. Integrin-linked kinase activity modulates the pro-metastatic behavior of ovarian cancer cells. Oncotarget. 2016;7(16):21968-81.

49. Bruney L, Conley KC, Moss NM, Liu Y, Stack MS. Membrane-type I matrix metalloproteinase-dependent ectodomain shedding of mucin 16/ CA-125 on ovarian cancer cells modulates adhesion and invasion of peritoneal mesothelium. Biol Chem. 2014;395(10):1221-31.

50. Vos MC, van Tillborg A, Brands WJ, Boll D, van Hamont D, van der Putten $H$, Pijlman B, van der Wurff, AAM, van Kuppevelt TH, LFAG M. Polymorphisms in MMP-14 and MMP-2 genes and ovarian cancer survival. Cancer Biomarkers. 2019;25(3):233-41.

51. Afzal S, Lalani EN, Poulsom R, Stubbs A, Rowlinson G, Sato H, Seiki M, Stamp GW. MT1-MMP and MMP-2 mRNA expression in human ovarian tumors: possible implications for the role of desmoplastic fibroblasts. Hum Pathol. 1998;29(2):155-65.

52. Davidson B, Goldberg I, Gotlieb WH, Kopolovic J, Ben-Baruch G, Nesland $J M$, Berner A, Bryne M, Reich R. High levels of MMP-2, MMP-9, MT1-MMP and TIMP-2 mRNA correlate with poor survival in ovarian carcinoma. Clin Exp Metastasis. 1999;17(10):799-808.

53. Davidson B, Goldberg I, Gotlieb WH, Kopolovic J, Ben-Baruch G, Nesland $J M$, Reich $R$. The prognostic value of metalloproteinases and angiogenic factors in ovarian carcinoma. Mol Cell Endocrinol. 2002;187(1-2):39-45.

54. Davidson B, Goldberg I, Gotlieb WH, Kopolovic J, Risberg B, Ben-Baruch G, Reich R. Coordinated expression of integrin subunits, matrix metalloproteinases (MMP), angiogenic genes and Ets transcription factors in advanced-stage ovarian carcinoma: a possible activation pathway? Cancer Metastasis Rev. 2003;22(1):103-15.

55. Davidson B, Goldberg I, Berner A, Nesland JM, Givant-Horwitz V, Bryne M, Risberg B, Kristensen GB, Trope CG, Kopolovic J, Reich R. Expression of membrane-type 1,2, and 3 matrix metalloproteinases messenger RNA in ovarian carcinoma cells in serous effusions. Am J Clin Pathol. 2001;115(4):517-24.

56. Sakata K, Shigemasa K, Nagai N, Ohama K. Expression of matrix metalloproteinases (MMP-2, MMP-9, MT1-MMP) and their inhibitors (TIMP-1, TIMP-2) in common epithelial tumors of the ovary. Int J Oncol. 2000;17(4):673-81.

57. Kamat AA, Fletcher M, Gruman LM, Mueller P, Lopez A, Landen CN, Han L, Gershenson DM, Sood AK. The clinical relevance of stromal matrix metalloproteinase expression in ovarian cancer. Clin Cancer Res. 2006:12(6):1707-14

58. Vos MC, Hollemans E, van der Steen S, van Kuppevelt TH, van der Wurff, A A M, Massuger L. Primary Ovarian Tumors With Lymphogenic and Hematogenic Metastasis Express High MMP-14, Which Colocalizes With Highly Sulfated Chondroitin Sulfate in the Stroma. Int J Gynecol Pathol. 2019.

59. Lin YG, Han LY, Kamat AA, Merritt WM, Landen CN, Deavers MT, Fletcher MS, Urbauer DL, Kinch MS, Sood AK. EphA2 overexpression is associated with angiogenesis in ovarian cancer. Cancer. 2007;109(2; 0008-543):332-40.

60. Brun JL, Cortez A, Commo F, Uzan S, Rouzier R, Darai E. Serous and mucinous ovarian tumors express different profiles of MMP-2, -7, -9, MT1-MMP, and TIMP-1 and -2. Int J Oncol. 2008:33(6):1239-46.

61. Vos MC, van der Wurff AA, Bulten J, Kruitwagen R, Feijen H, van Kuppevelt TH, Hendriks T, Massuger LF. Limited independent prognostic value of MMP-14 and MMP-2 expression in ovarian cancer. Diagn Pathol. 2016:11:34.

62. Vos MC, Hollemans E, Ezendam N, Feijen H, Boll D, Pijlman B, van der Putten $H$, Klinkhamer $P$, van Kuppevelt TH, van der Wurff AA, Massuger LF. MMP-14 and CD44 in Epithelial-to-Mesenchymal Transition (EMT) in ovarian cancer. J Ovarian Res. 2016;9(1):53.

63. Paulsen T, Ree AH, Kaern J, Kjaerheim K, Bassarova A, Berner A, Haldorsen T, Trope C, Nesland JM. Expression of matrix metalloproteinase-2 in serous borderline ovarian tumors is associated with noninvasive implant formation. Eur J Gynaecol Oncol. 2007;28(5):356-63.

64. Torng PL, Mao TL, Chan WY, Huang SC, Lin CT. Prognostic significance of stromal metalloproteinase-2 in ovarian adenocarcinoma and its relation to carcinoma progression. Gynecol Oncol. 2004;92(2):559-67.

65. Kato N, Motoyama T. Relation between laminin- 5 gamma 2 chain and cell surface metalloproteinase MT1-MMP in clear cell carcinoma of the ovary. Int J Gynecol Pathol. 2009;28(1):49-54.

66. Wang Q, Zhan Y, Ling S, Huang H, Zhang Y, Chen G, Huang S, Li C, Guo W. Rapid and Nondestructive Histopathological Analysis for Intraoperative Cancer Diagnosis Using an Enzyme-Activated NIR-II Nanoprobe. Angew Chem Int Ed Engl. 2020.

67. Kikkawa F, Kajiyama H, Shibata K, Ino K, Nomura S, Mizutani S. Dipeptidyl peptidase IV in tumor progression. Biochim Biophys Acta. 2005;1751(1):45-51.

68. Lin SW, Ke FC, Hsiao PW, Lee PP, Lee MT, Hwang JJ. Critical involvement of ILK in TGFbeta1-stimulated invasion/migration of human ovarian cancer cells is associated with urokinase plasminogen activator system. Exp Cell Res. 2007;313(3):602-13. 
69. Cowden Dahl KD, Zeineldin R, Hudson LG. PEA3 is necessary for optimal epidermal growth factor receptor-stimulated matrix metalloprotein ase expression and invasion of ovarian tumor cells. Mol Cancer Res. 2007;5(5):413-21.

70. Devine KM, Smicun Y, Hope JM, Fishman DA. S1P induced changes in epithelial ovarian cancer proteolysis, invasion, and attachment are mediated by Gi and Rac. Gynecol Oncol. 2008;110(2):237-45.

71. Moss NM, Liu Y, Johnson JJ, Debiase P, Jones J, Hudson LG, Munshi HG, Stack MS. Epidermal growth factor receptor-mediated membrane type 1 matrix metalloproteinase endocytosis regulates the transition between invasive versus expansive growth of ovarian carcinoma cells in threedimensional collagen. Mol Cancer Res. 2009;7(6):809-20.

72. Jiang L, Siu MK, Wong OG, Tam KF, Lam EW, Ngan HY, Le XF, Wong ES, Chan HY, Cheung AN. Overexpression of proto-oncogene FBI-1 activates membrane type 1-matrix metalloproteinase in association with adverse outcome in ovarian cancers. Mol Cancer. 2010;9:318.

73. Ling Poon S, Lau MT, Hammond GL, Leung PC. Gonadotropin-releasing hormone-II increases membrane type I metalloproteinase production via beta-catenin signaling in ovarian cancer cells. Endocrinology. 2011;152(3):764-72.

74. Nakayama I, Shibazaki M, Yashima-Abo A, Miura F, Sugiyama T, Masuda T, Maesawa C. Loss of HOXD10 expression induced by upregulation of miR$10 \mathrm{~b}$ accelerates the migration and invasion activities of ovarian cancer cells. Int J Oncol. 2013;43(1):63-71.

75. Yang Y, Jiang Y, Wan Y, Zhang L, Qiu J, Zhou S, Cheng W. UCA1 functions as a competing endogenous RNA to suppress epithelial ovarian cancer metastasis. Tumour Biol. 2016:37(8):10633-41.
76. Semprucci E, Tocci P, Cianfrocca R, Sestito R, Caprara V, Veglione M, Castro VD, Spadaro F, Ferrandina G, Bagnato A, Rosano L. Endothelin A receptor drives invadopodia function and cell motility through the beta-arrestin/PDZ-RhoGEF pathway in ovarian carcinoma. Oncogene. 2016;35(26):3432-42.

77. Duan Y, Dong Y, Dang R, Hu Z, Yang Y, Hu Y, Cheng J. MiR-122 inhibits epithelial mesenchymal transition by regulating P4HA1 in ovarian cancer cells. Cell Biol Int. 2018;42(11):1564-74.

78. Wang L, Madigan MC, Chen H, Liu F, Patterson Kl, Beretov J, O'Brien PM, Li Y. Expression of urokinase plasminogen activator and its receptor in advanced epithelial ovarian cancer patients. Gynecol Oncol. 2009;114(2):265-72.

79. Trudel D, Desmeules P, Turcotte S, Plante M, Gregoire J, Renaud MC, Orain M, Bairati I, Tetu B. Visual and automated assessment of matrix metalloproteinase-14 tissue expression for the evaluation of ovarian cancer prognosis. Mod Pathol. 2014;27:1394-1404.

80. Takahashi M, Tsunoda T, Seiki M, Nakamura Y, Furukawa Y. Identification of membrane-type matrix metalloproteinase-1 as a target of the beta-catenin/Tcf4 complex in human colorectal cancers. Oncogene. 2002;21(38):5861-7.

\section{Publisher's Note}

Springer Nature remains neutral with regard to jurisdictional claims in published maps and institutional affiliations.
Ready to submit your research? Choose BMC and benefit from:

- fast, convenient online submission

- thorough peer review by experienced researchers in your field

- rapid publication on acceptance

- support for research data, including large and complex data types

- gold Open Access which fosters wider collaboration and increased citations

- maximum visibility for your research: over $100 \mathrm{M}$ website views per year

At BMC, research is always in progress.

Learn more biomedcentral.com/submissions 